Esteban-Vázquez, B.L., De los Palos-Peña, M., SolísMarín, F.A., \& Laguarda-Figueras, A. (2021). Morphology of endoskeleton and spination in the sea star Midgardia xandaros (Brisingida: Brisingidae) from the Gulf of Mexico. Revista de Biologia Tropical, 69(S1), 404-422. DOI 10.15517/rbt. v69iSuppl.1.46381

\title{
Morphology of endoskeleton and spination in the sea star Midgardia xandaros (Brisingida: Brisingidae) from the Gulf of Mexico
}

\author{
Brenda Lizbeth Esteban-Vázquez ${ }^{1 *}$ \\ Magdalena De los Palos-Peña ${ }^{2}$ \\ Francisco Alonso Solís-Marín ${ }^{3}$ \\ Alfredo Laguarda-Figueras ${ }^{3}$
}

1. Facultad de Ciencias, Universidad Nacional Autónoma de México, Ciudad de México, México; brendaestebanv@ gmail.com (*Correspondence).

2. Posgrado en Ciencias del Mar y Limnología, Universidad Nacional Autónoma de México, Ciudad de México, México; mdelospalos@ciencias.unam.mx

3. Colección Nacional de Equinodermos "Dra. Ma. E. Caso Muñoz", Laboratorio de Sistemática y Ecología de Equinodermos, Instituto de Ciencias del Mar y Limnología, Universidad Nacional Autónoma de México, Ciudad de México, México; fasolis@cmarl.unam.mx, laguarda@cmarl.unam.mx

Received 15-VII-2020. Corrected 10-IX-2020. Accepted 26-X-2020.

\begin{abstract}
Introduction. The deep-sea asteroid species of Brisingida have a nearly global distribution but have remained poorly understood due to their deep bathymetric distributions and fragile skeletons. Objective. To describe the external and internal morphology of Midgardia xandaros including the skeletal arrangement, through multifocal and SEM techniques. Methods. We examined a total of 21 specimens, including 27 arm fragments, from the Gulf of Mexico and Honduras. Two specimens were dissected. Results. Detailed descriptions of pedicellariae, abactinal, intercostal, inferomarginal, adambulacral, ambulacral, odontophore, and oral ossicles, and their spines are provided, emphasizing the articulations and muscle attachments. C-shaped valves pedicellariae and small pedicellariae valves with shorter denticulation areas were recognized. Conclusions. The morphological description of M. xandaros is expanded, providing the most extensive description of abactinal, first adambulacral, first and subsequent inferomarginal ossicles, abactinal spines, and C-shaped, crossed pedicellariae, as well as the distal arm plates, for a brisingid species using SEM to date.
\end{abstract}

Key words: ossicles; oral frame; pedicellariae; spines; deep-sea.

Brisingids are deep-sea asteroids that have a body shape similar to ophiuroids due to their small, circular disk, which is clearly differentiated from their six to twenty, long and slender arms. They also resemble crinoids when they raise their long, spined arms into the water column for suspension feeding (Clark \& Downey, 1992; Mah \& Blake, 2012; Gale, Mah, Hamel \& Mercier, 2014).

The species of Brisingida Fisher, 1928 have a nearly global distribution but have remained poorly understood due to their deep bathymetric distributions and fragile skeletons. They were initially considered as one family, but after comparison of all the genera from the Atlantic waters, two well-defined families were designated: Brisingidae Sars, 1875 and Freyellidae Downey, 1986 (Downey, 1986; Clark \& Mah, 2001; Gale et al., 2014).

The family Brisingidae is defined by lacking bare interradial plates on the disk, and having arms constricted at their base whose 
abactinal plates form costae, and includes the genus Midgardia Downey, 1972 (Downey, 1986; Zhang, Wang, Zhou, \& Zhang, 2019). This genus is distinguished by having 11 to 13 deciduous arms, constricted at their base, and acute interradial arcs; bare interradial plates absent on the disk and numerous, remarkable costae made up of imbricate plates (Downey, 1986). It includes only one species, Midgardia xandaros Downey, 1972, whose type locality is Veracruz, Mexico (19²'36" N \& 95'27'30" $\mathrm{W}, 457.2 \mathrm{~m}$ ), and has been reported for the Gulf of Mexico and Honduras (366 to 475 m) (Downey, 1972; Pequegnat, Gallaway \& Pequegnat, 1990; Clark \& Downey, 1992; Durán-González, Laguarda-Figueras, SolísMarín, Buitrón-Sánchez \& Torres-Vega, 2005; Solís-Marín et al., 2013).

In the 19th century, asteroid ossicles started to be described as part of taxonomic studies (e.g. Agassiz, 1877; Viguier, 1879; Ludwig, 1897), providing the foundations and terminology for future skeleton morphological works. In particular, Sars (1875) described Hymenodiscus coronata (= Brisinga coronata), giving details and illustrations of the skeleton, pedicellariae, spines, muscles, nervous and digestive systems, as well as notes about its regenerative capacity and ontogeny. Until now, Sars (1875) work has been the most extensive description for a brisingid species.

Subsequent taxonomic studies about brisingids have largely been based on external morphology (e. g. Fisher, 1917; Fisher, 1918; Fisher, 1928; Baranova, 1957; Tortonese, 1958; Downey, 1972; Downey, 1973; Downey, 1986; Clark \& Downey, 1992; McKnight, 2006; Benavides-Serrato, Borrero-Pérez, \& Díaz-Sánchez, 2011; Mah, 2016; Zhang et al., 2019; Zhang, Zhou, Xiao, \& Wang, 2020). Meanwhile, Spencer and Wright (1966), Blake (1987) and Gale (1987) mainly provided insights into the skeletal morphology of brisingids at an ordinal level, emphasizing the arrangement of the ossicles of the oral frame.

Regarding pedicellariae morphology, Emson and Young (1994) provided the first Scanning Electron Microscopy (SEM) photographs of brisingid pedicellariae, describing them in great detail and making morphological comparisons with Labidiaster annulatus Sladen, 1889 and Stylaterias forreri (deLoriol, 1887). Also, Mah (1999) in his taxonomic work of Brisingaster robillardi (deLoriol, 1883), showed SEM photographs of pedicellariae for this species and Novodinia helenae Rowe (1989). Finally, Vickery and McClintock (2000) described the tube-feet of brisingids as semi-flat-tipped and non-suckered, proposing their morphology as a taxonomic character at an ordinal level.

Recently, the phylogenetic studies of Gale (2011) and Fau and Villier (2019) provided well-described ossicles of brisingids, using SEM techniques, and updating the skeletal terminology for asteroids in general. Likewise, Fau and Villier (2018) described the first ambulacral ossicles of $B$. robillardi. However, they showed isolated ossicles from different brisingid species; therefore, the complete description of the skeleton of a brisingid species is still needed. Here, we describe the external and internal morphology of Midgardia xandaros Downey, 1972, including the skeletal arrangement, through multifocal and SEM techniques, also providing additional notes about the general morphology of a brisingid.

\section{MATERIALS AND METHODS}

Study area: The Gulf of Mexico is a semi-enclosed ocean basin located between Cape Sable, Florida, United States and Cabo Catoche, Quintana Roo, Mexico. It has a shoreline extension of $5696 \mathrm{~km}$ and a mean water depth of $1615 \mathrm{~m}$ (Fautin et al., 2010; Turner \& Rabalais, 2019). It also receives a vast sediment discharge from the Mississippi Delta, and other rivers such as Coatzacoalcos and Papaloapan, making the deep-sea floor terrigenous and muddy. In contrast, the platforms of Florida and Yucatan Peninsula have carbonate sediments (Armstrong-Altrin et al., 2015; Ramos-Vázquez, Armstrong-Altrin, RosalesHoz, Machain-Castillo \& Carranza-Edwards, 2017; Ward \& Tunnell, 2017). The deepest 
area of the Gulf of Mexico is the Sigsbee Abyssal Plain which ranges from 3750 to $4400 \mathrm{~m}$ (Fautin et al., 2010; Turner \& Rabalais, 2019).

The water circulation is mainly given by the Loop Current that originates at the Yucatan Channel, which connects the Gulf of Mexico with the Caribbean Sea and is a semi-enclosed basin located between $9^{\circ} \mathrm{N}$ and $22^{\circ} \mathrm{N}$ latitude and $60^{\circ} \mathrm{W}$ and $89^{\circ} \mathrm{W}$ longitude. The Caribbean deep-sea has many small canyons, seamounts, and table mounts, such as the Explorer Bank, located off Honduras (Miloslavich et al., 2010; Palanisamy, Becker, Meyssignac, Henry, \& Cazenave, 2012; Ward \& Tunnell, 2017).

Specimen examination: A total of 21 specimens and 27 arm fragments deposited at the National Echinoderm Collection "Dra. Ma. Elena Caso Muñoz" (ICML-UNAM) and the National Museum of Natural History, Smithsonian Institution (USNM), and previously collected in the Gulf of Mexico and Honduras, were examined through a stereoscopic microscope (Olympus SZX7).

The following measurements were taken for each specimen: minor radius (r), disk diameter $\left(D_{D}\right)$ and disk height $\left(D_{H}\right)$, if possible, using a digital caliper (TRUPER Caldi-6MP). Photographs of the main morphological structures and spination were taken with a multifocal microscope (Leica Z16 APO A; Olympus SZX-12 MDU) at Laboratorio de Microscopía y Fotografía de la Biodiversidad II, Instituto de Biología (IB), UNAM, and Imaging Scanning Electron Microscopy Laboratory, Smithsonian Institution.

SEM samples: Two specimens were dissected according to the method described by Fau and Villier (2018). Fragments of arms, disk and oral frame, as well as spines and pedicellariae, were immersed in a dilute solution of household bleach (20-40 \%) followed by several rinses in sterile water and alcohol (70 \%), dried, mounted and gold-coated on aluminum stubs. The samples were visualized on a Scanning Electron Microscope (HITACHI SU1510; JEOL JSM6360LV) at the Laboratorio de
Microscopía y Fotografía de la Biodiversidad I, IB, UNAM, and the SEM Academic Service, ICML, UNAM.

The description of ossicles, spines and pedicellariae follows the terminology proposed by Chia and Amerongen (1975), Clark and Downey (1992), Emson and Young (1994), Gale (2011), Fau and Villier (2018), and Fau and Villier (2019) (Appendix 1).

\section{RESULTS}

\section{Systematics}

Midgardia xandaros Downey, 1972

Midgardia xandaros Downey, 1972: 422-425;

Downey, 1973: 99; Downey, 1986: 19-20; Clark \& Downey, 1992: 470-471.

Description: The 21 specimens and 27 arm fragments have the following range in dimensions: $r=13-19.3 \mathrm{~mm}, \mathrm{D}_{\mathrm{D}}=29-38.2$ $\mathrm{mm}$, and $\mathrm{D}_{\mathrm{H}}=5-8.9 \mathrm{~mm}$. Due to the lack of complete specimens, $\mathrm{R}$ was not measured, except for the holotype $(\mathrm{R}=680 \mathrm{~mm})$.

Disk small, round, flat. The abactinal membrane of the disk is thin and delicate, so stomach fragments may be visible abactinally (Fig. 1A, Fig. 1B, Fig. 1C, Fig. 1D). Abactinal plates are small, irregularly oval-shaped, and irregularly scattered over the membrane, with a central, elevated boss which holds a tiny, hyaline, round based, acute spinelet whose trabeculae are not well-defined (Fig. 1E, Fig. 1F, Fig. 1G). Occasionally, there are two spinelets per abactinal plate. Madreporite in interradial position, small respect to the disk, hemispherical, tumid, raised. Two round papulae occur at the base of each arm (Fig. 1H). The anus is inconspicuous, surrounded by longer abactinal spinelets (Fig. 1I, Fig. 1J).

Arms 11 to 13 are long, thin, and fragile, except in the robust gonadal region. Two paired gonads with up to five saccules. This region has numerous irregular, narrow, well-marked costae; some rows may be incomplete (Fig. 2A, Fig. 2B). Each costae row is made up of irregular, elongated, abactinal plates imbricated by two costcost articulations. Each abactinal 


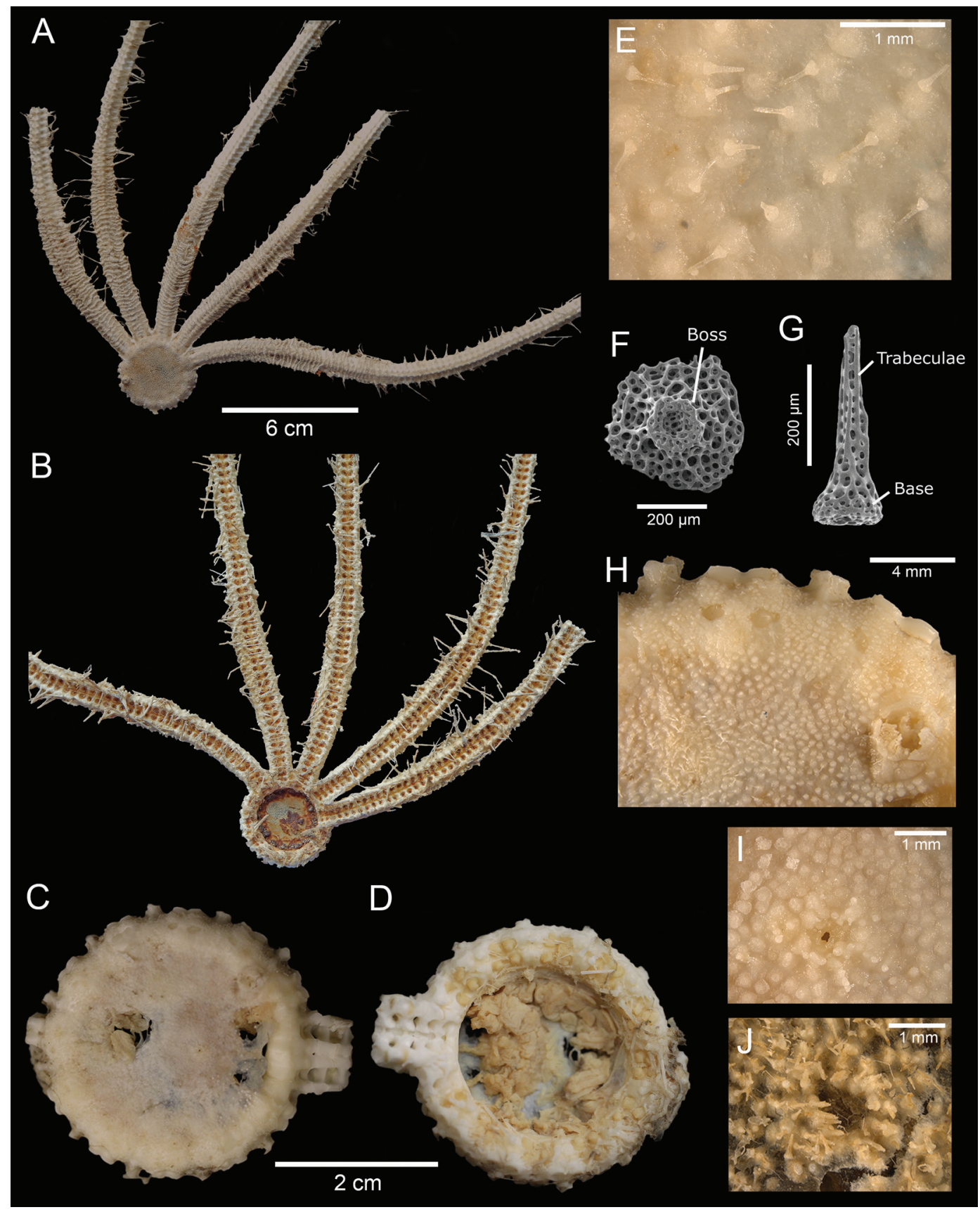

Fig. 1. Midgardia xandaros Downey, 1972. Body morphology and disk. A. Holotype (abactinal view). B. Holotype (actinal view). C. Abactinal surface of the disk. D. Actinal surface of the disk. E. Abactinal ossicles of the disk. F. Abactinal ossicle of the disk. G. Abactinal spinelet of the disk. H. Madreporite and papulae. I. Anus. J. Anus surrounded by spinelets. (USNM 11420: A-B; ICML-UNAM 2.196.2: C-I; ICML-UNAM 2.196.0: J). 


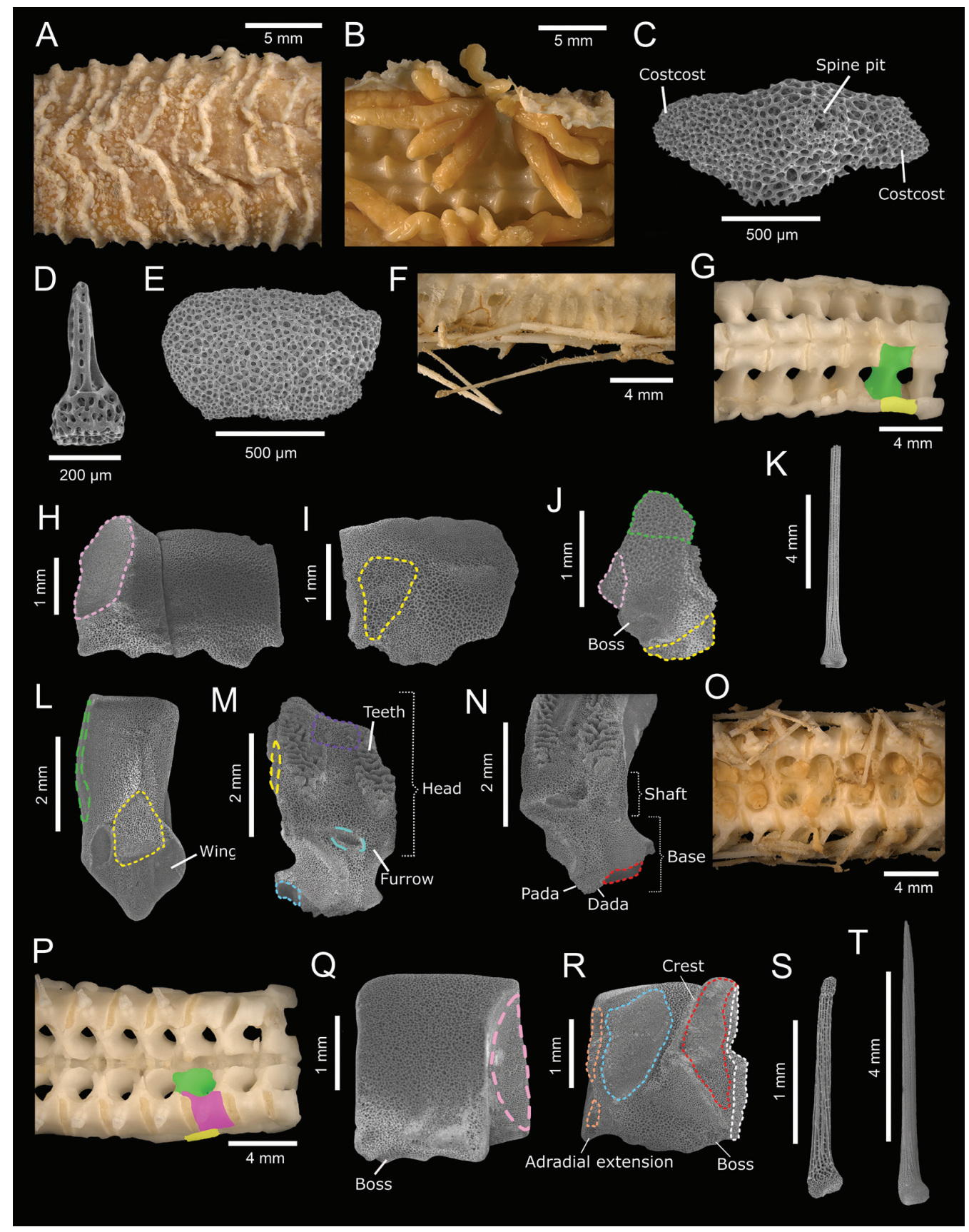

Fig. 2. Midgardia xandaros Downey, 1972. ICML-UNAM 2.196.2. Ossicles and spines from gonadal region. A. Costae rows. B. Gonads. C. Costae (abactinal view). D. Costae spinelet. E. Intercostal (abactinal view). F. Inferomarginal spines. G. Arm bare (abactinal view). H. Inferomarginal (abactinal view). I. Inferomarginal (actinal view). J. Inferomarginal tubercle-shaped (abactinal view). K. Inferomarginal spine. L. Ambulacral (abactinal view). M.: Ambulacral (actinal view). N. Ambulacral wings (actinal view). O. Arm (actinal view). P. Arm bare (actinal view). Q. Adambulacral (actinal view). R. Adambulacral (abactinal view). S. Adambulacral spine. T. Subambulacral spine. In aqua (dashed): actam; blue: padam; green: imabt; green (dashed): lim; green (solid): ambulacral; orange: pada; pink: imim; pink (dashed): interadam; purple: abtam; red: dadam; white: dada; yellow: amim; yellow (dashed): lia; yellow (solid): inferomarginal. 
plate has a low boss and an acute spinelet with a thick base that is shorter than the spinelets on the disk (Fig. 2C, Fig. 2D). The robust, tumid costae plates are joined to inferomarginal plates by imabt. Between costae rows, there are small, asymmetrical, flat, fragile intercostal plates, and tiny, round granules embedded in the abactinal membrane (Fig. 2E).

Inferomarginal plates constitute the margin along the arms; proximally, they are wider than long and have a large, downwards boss with an oval spine pit; beyond the gonadal region, they are shorter like a tubercle. They are joined with the following inferomarginal plate through imim, and the ambulacral plates by amim (Fig. 2F, Fig. 2G, Fig. 2H, Fig. 2I, Fig. 2J). One inferomarginal spine very long, prominent, acute, hyaline, laterally adpressed and fragile, so frequently it is broken (Fig. 2K). Beyond the gonadal region, instead of costae rows, there are transversal bands of diminutive pedicellariae, and the abactinal membrane is thinner, making the adambulacral and ambulacral plates more visible.

Ambulacral plates are longer than wide, have a round top, with a shaft slightly waisted whose stereom is labyrinthic. The base has a semitriangular amim articulation and two very short, curved wings (Fig. 2L). Actinally, the plates possess two areas of short teeth and moderately broad abtam surface at the head, a shallow furrow and small, oval-shaped actam area. The wings are in contact with adambulacral plates through dadam and padam. Laterally, two ambulacrals of the same column are joined by lim and its lia articulation (Fig. 2M, Fig. 2N). Superambulacral plates absent. Ambulacral feet biseriate, long, robust, with a small sucker (Fig. 2O).

Adambulacral plates small, high, slightly longer than wide (Fig. 2P). Abactinally, they have a curved top, a conspicuous, diagonal crest which separates padam and dadam muscles, as well as dada and pada articulations, allowing them the attachment with ambulacral plates. The adradial extension is quite short and angular. In actinal view, two adjacent adambulacral plates of the same row along the arm are joined laterally by interadam. Their ambulacral margin is slightly acute and has three or four small, shallow bosses for small, elongate, thin, tubercle base, acicular adambulacral spines in both proximal and distal edges (Fig. 2Q, Fig. 2R, Fig. 2S). One subambulacral spine long, acicular and more robust than adambulacral ones, with well-defined, straight trabeculae (Fig. 2T). The ambulacral groove is moderately broad. Actinal plates absent.

The most distal ambulacral, adambulacral and inferomarginal plates are smaller and their shape is modified (Fig. 3A). The ambulacral plates have a well-marked shaft, making an apex longer than wide, almost triangular, and the base has short, angular but more noticeable wings. In actinal view, the ambulacral plates do not show remarkable teeth (Fig. 3B, Fig. 3C). In respect to the adambulacral plates, they are longer than wide, with an inconspicuous interradial extension, less extensive interadam and more curved adambulacral furrow, having only a subambulacral boss and poorly developed crest (Fig. 3D, Fig. 3E). In contrast, the inferomarginal plates continue decreasing in size and the boss occupies almost all its abactinal surface, having a well-marked spine pit (Fig. 3F).

The rigid oral frame is composed of the two first ambulacral plates, and two oral plates joined by an odontophore, forming the contour of the disk (Fig. 3G, Fig. 3H, Fig. 3I, Fig. 3J, Fig. 3K, Fig. 3L).

First ambulacral plate long, high, narrow with a curved apex, and base without wings since there is no attachment with adambulacral plates (Fig. 3M). Two adjacent first ambulacral plates are joined through their radial surface which has the lim and its respective lia on a short process. In contrast to the ambulacral plates from the gonadal region, the abtam and teeth area are wider, and the actam is shallower (Fig. 3N, Fig. 3O). Interradially, they have an expansive, flat area for procoam and procoa, a diagonal bridge, rugous dicoa and dicoam areas, and smaller doda (Fig. 3P).

The oral plate is longer than the first ambulacral plate, with a curved, laterally flattened ramus, and contracted in the middle of the 


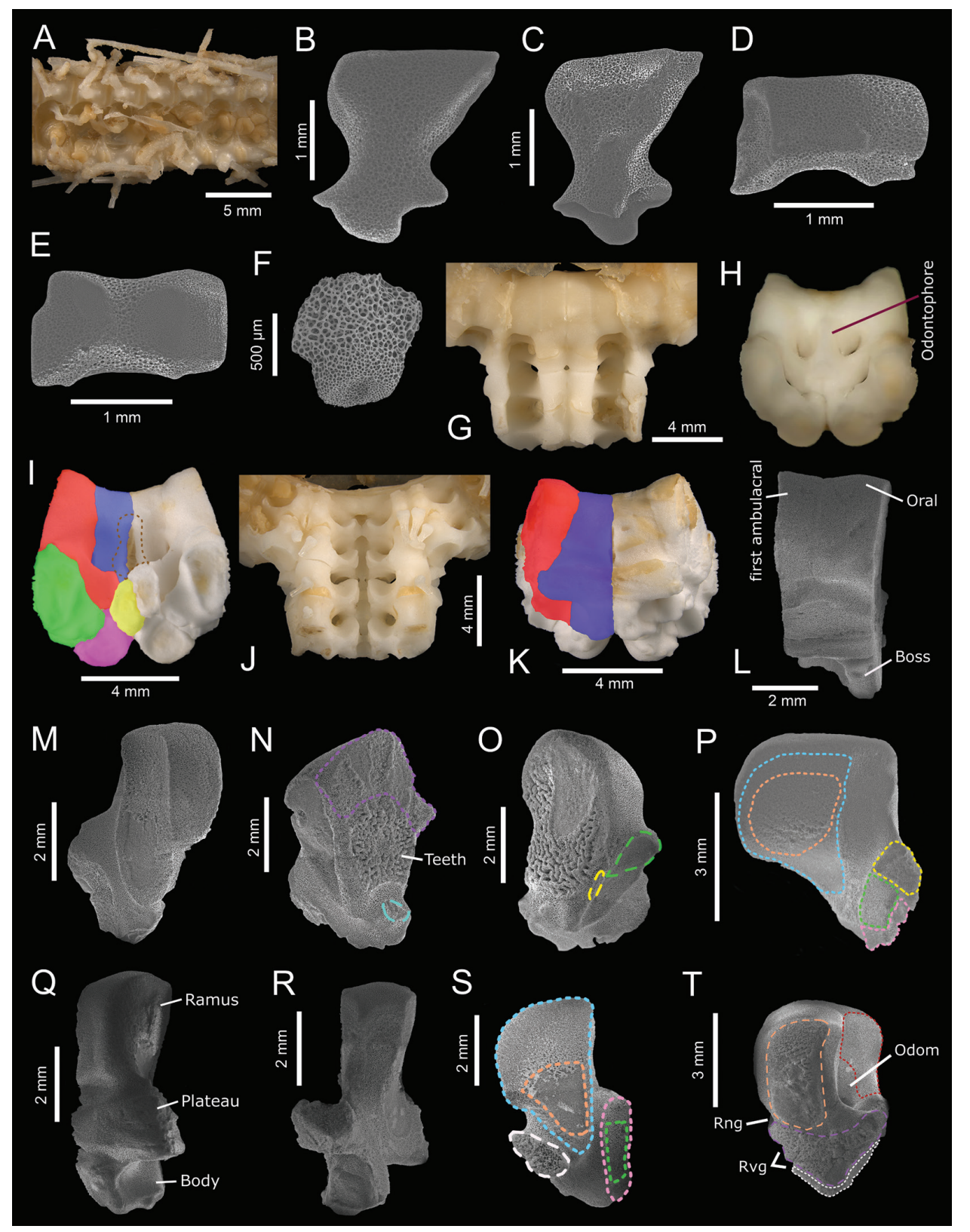

Fig. 3. Midgardia xandaros Downey, 1972. Distal arm ossicles: A-F. Oral frame ossicles and spines: G-T. A. Ambulacral furrow. B. Ambulacral (abactinal view). C. Ambulacral (actinal view). D. Adambulacral (actinal view). E. Adambulacral (abactinal view). F. Inferomarginal (abactinal view). G. Arm base (abactinal view). H. Odontophore insertion. I. Fragment of the oral frame (abactinal view). J. Arm base (actinal view). K. Fragment of the oral frame (actinal view). L. Oral and first ambulacral (actinal view). M. First ambulacral (actinal view). N-O: First ambulacral (radial view). P. First ambulacral (interradial view). Q. Oral (actinal view). R. Oral (abactinal view). S. Oral (radial view). T. Oral (interradial view). In aqua (dashed): actam; blue: procoa; blue (solid): oral; brown: odontophore; green: dicoam; green (dashed): lim; green (solid): second ambulacral; orange: procoam; orange (dashed): abiim; pink: dicoa; pink (solid): first ambulacral; purple: abtam; purple (dashed): iioa; red: poda; red (solid): first ambulacral; white: aciim; white (dashed): riom; yellow: doda; yellow (dashed): lia; yellow (solid): first inferomarginal. (ICML-UNAM 2.196.2: A-G, J, L-N, P-T; ICML-UNAM 2.196.0: H, K, O). 
plate; the plateau is longer than wide, extensive and has three shallow furrows for rng and rvg, and the body is short, quite concave interradially, oval (Fig. 3Q). In abactinal view, the ramus has a curved top and a prominent, raised platform; the plateau resembles wings because of their lateral extension, and the body has a narrow projection raised from the midradial oral line (Fig. 3R). In radial view, the ramus is very prominent, having an extensive area for procoa and procoam, and the body has quite a deep furrow; laterally, there is a narrow surface for dicoa and dicoam, and the elevated process which holds the riom (Fig. 3S). Interradially, oral plates are joined by abiim, iioa and aciim, showing numerous gyri; they also have a depth orifice of odontophore attachment (odom) whose poda is quite flat, with shallow rng and rvg furrows (Fig. 3T).

The odontophore is longer than wide, with an apical, triangular-shaped shelf, and contracted in the middle of the plate. It articulates with oral plates through odom and poda and first ambulacral plates by only doda; it also has a rectangular base where odomim joins with inferomarginal plates. First inferomarginal plates semitriangular, quite concave (Fig. 4A, Fig. 4B, Fig. 4C, Fig. 4D, Fig. 4E).

Three or four long, thin, blunt, oral spines with a round base are present which are inserted both in the middle and distal edge of the oral plate; their trabeculae are long, delicate (Fig. 4F, Fig. 4G). One suboral spine is longer, thin, acicular, with well-marked, moderately wide trabeculae and more robust than the suboral ones (Fig. 4H).

The second ambulacral plates are narrower than the first ambulacral ones and have very short wings, almost inconspicuous (Fig. 4I, Fig. 4J, Fig. 4K). Meanwhile, the first adambulacral plates are modified into an angular, elevated ossicle, having an apical, conspicuous boss for subambulacral spines (Fig. 4L, Fig. 4M, Fig. 4N).

Large crossed pedicellariae are scattered over the abactinal surface of the disk and ambulacral furrow (Fig. 4O, Fig. 4P, Fig. 4Q). Their valves are $\mathrm{C}$-shaped with three to four canines at the top, an oval, deep diastema, up to 25 diminutive teeth in the medial projection, and long, spatulate base. The canines of both valves correspond to each other. Small abd and concave add surfaces (Fig. 4R, Fig. 4S, Fig. 5A, Fig. 5B).

Tiny crossed pedicellariae cover marginal, oral, suboral, adambulacral and subambulacral spines and some costae rows. They also constitute the transverse bands along the arms abactinally. These pedicellariae have two small, quite curved valves with five to seven lateral canines, a double row of median, central, short teeth and little-marked diastema; their medial projection has a double row of up to 13 diminutive teeth, and the base is slightly spatulate and round (Fig. 5C, Fig. 5D, Fig. 5E). Their basal plate is longer than wide, with two short, blunt terminal pegs and a curved articular ridge. On the external surface of the valves, there is a group of holes at the middle and base of the valves where abd and add inserts (Fig. 5F, Fig. 5G, Fig. 5H).

Color in life: Bright red (Downey, 1972).

Geographic and bathymetric distribution: North of Cay Sal Bank, Florida, United States to Honduras (366-1280 m) (Fig. 6).

Material examined: ICML-UNAM 2.196.0 (Laguna Madre, Tamaulipas, Mexico; 245'' " N \& 96²9'10.8” W; $760 \mathrm{~m}$; $\mathrm{N}=$ $2 ; \mathrm{D}_{\mathrm{D}}=31.9 \mathrm{~mm}$, dissected). ICML-UNAM 2.196.1 (Soto la Marina, Tamaulipas, Mexico; 233'36.78” N \& 97²1'30.24” W; 406 $\mathrm{m} ; \mathrm{N}=2$ ). ICML-UNAM 2.196.2 (Coatzacoalcos, Veracruz, Mexico; 18 $57^{\prime} 107^{\prime \prime} \mathrm{N}$ \& 94²0'027' W; $671.9 \mathrm{~m} ; \mathrm{N}=2 ; \mathrm{D}_{\mathrm{D}}=29.4$ $\mathrm{mm}$, dissected). ICML-UNAM 2.196.3 (Laguna Mecoacan, Tabasco, Mexico; 19³2'30" $\mathrm{N} \& 92^{\circ} 49^{\prime} 41.22^{\prime}$ ' W; $561 \mathrm{~m}$; $\mathrm{N}=1$ ). ICMLUNAM 11525 (Laguna Madre, Tamaulipas, Mexico; 253'24.06” N \& 96'16'34.38” W; 995 m; N=1). ICML-UNAM 11566 (Laguna Madre, Tamaulipas, Mexico; 245' $50.28^{\prime \prime} \mathrm{N}$ \& 96³3'34.98" W; $584 \mathrm{~m}$; N=1). ICMLUNAM 11664 (Barra Chiltepec, Tabasco, 


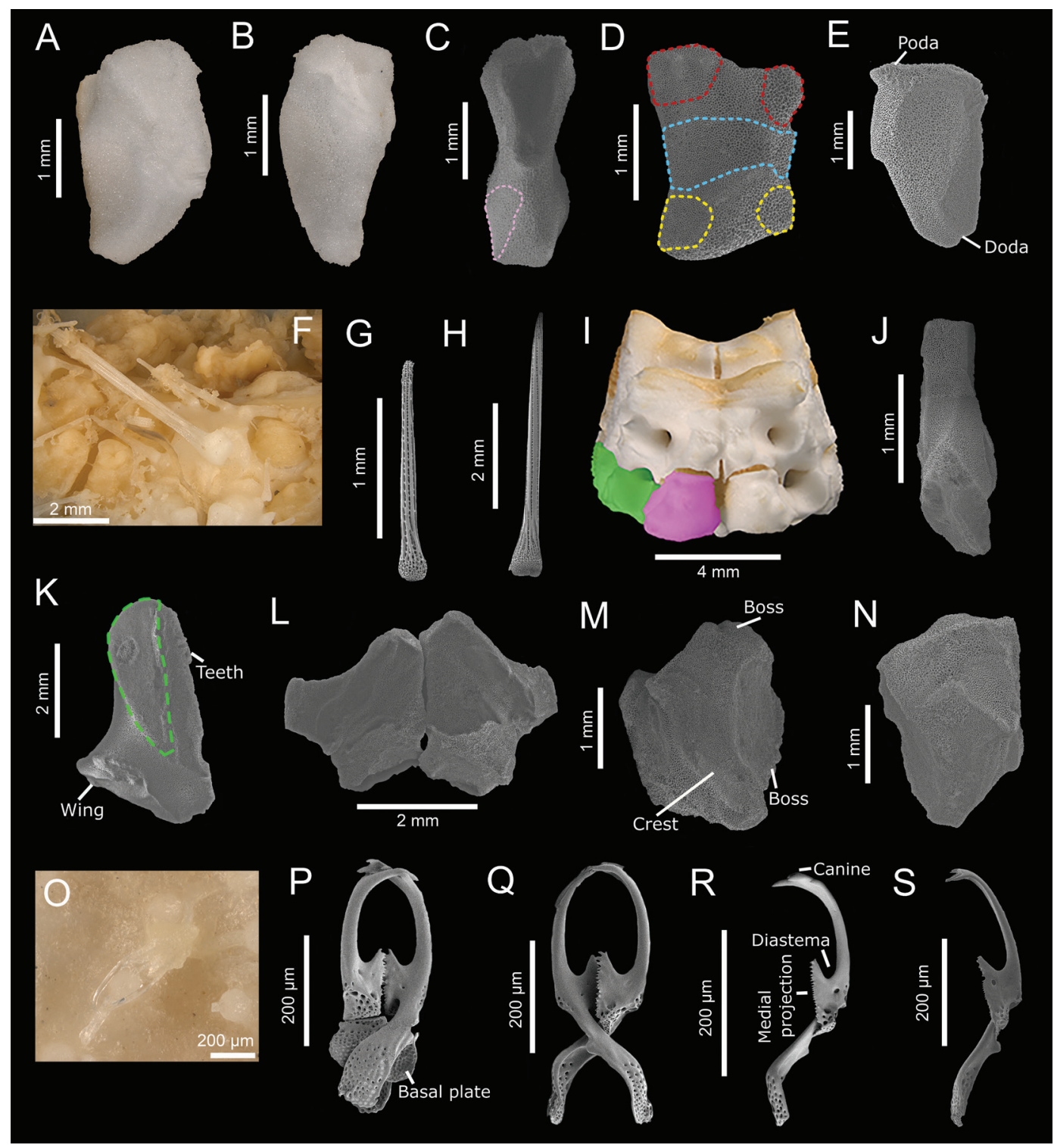

Fig. 4. Midgardia xandaros Downey, 1972. Oral frame and arm base ossicles: A-N. Pedicellariae: O-S. A, C: Odontophore (actinal view). B, D: Odontophore (actinal view); E: Odontophore (interradial view); F-G: Oral spines. H: Suboral spine. I: Fragment of oral frame (actinal view). J: Second ambulacral plate (abactinal view). K: Second ambulacral plate (radial view). L-M: First adambulacral plates (actinal view). N: First adambulacral plate (actinal view). O: Pedicellariae of the disk. P-Q: Large C-shaped crossed pedicellariae. R-S: C-shaped valves. In blue: odom; green (dashed): lim; green (solid): second ambulacral; pink: odomim; pink (solid): first adambulacral; red: poda; yellow: doda. (ICML-UNAM 2.196.0: A-B, I; ICML-UNAM 2.196.2: C-H; J-R. USNM E 11420: S).

Mexico; 19³3'16.26” N \& 9249'5.76” W; $593 \mathrm{~m} ; \mathrm{N}=3$ ). ICML-UNAM 11748 (Tonala, Tabasco, Mexico; 18 $58^{\prime} 3.48^{\prime \prime} \mathrm{N} \&$ 947'34.62" W; $710 \mathrm{~m} ; \mathrm{N}=2$ ). ICML-UNAM
12647 (Sanchez-Magallanes, Tabasco, Mexico; $19^{\circ} 13^{\prime} 40.5^{\prime \prime} \mathrm{N}$ \& 9354'51.42” W; $746 \mathrm{~m}$; $\mathrm{N}=13$ arm fragments). ICML-UNAM 12667 (Frontera, Tabasco, Mexico; 19³2’49.56” N 


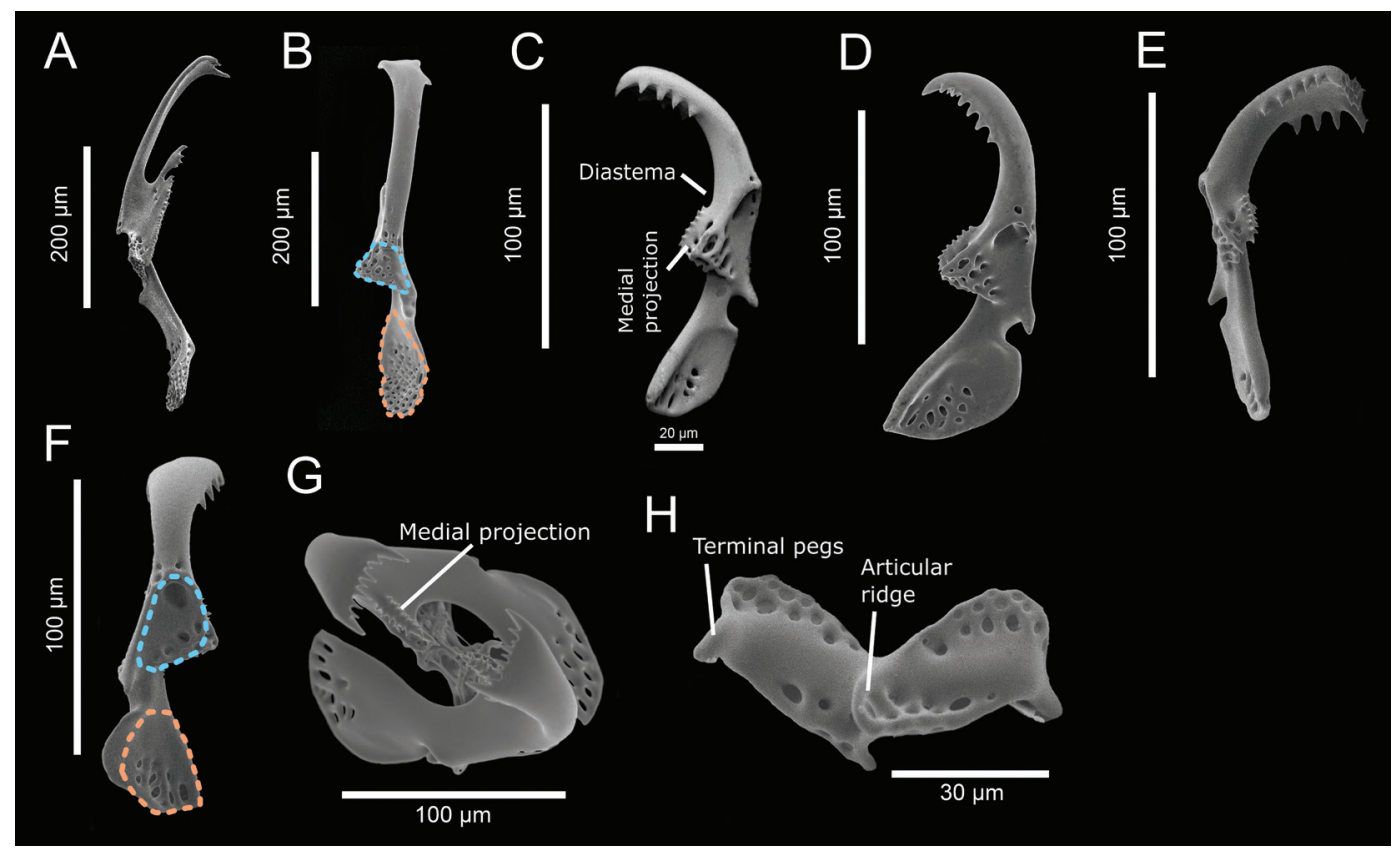

Fig. 5. Midgardia xandaros Downey, 1972. Pedicellariae. A-B: C-shaped valves. C-F: Tiny spatulate-shaped valves. G: Tiny spatulate-shaped pedicellariae. H: Basal plate of tiny spatulate-shaped pedicellariae. In blue: abd; orange: add. (ICMLUNAM 2.196.0: A, C, E, G; USNM E 11420: B, D, F, H).

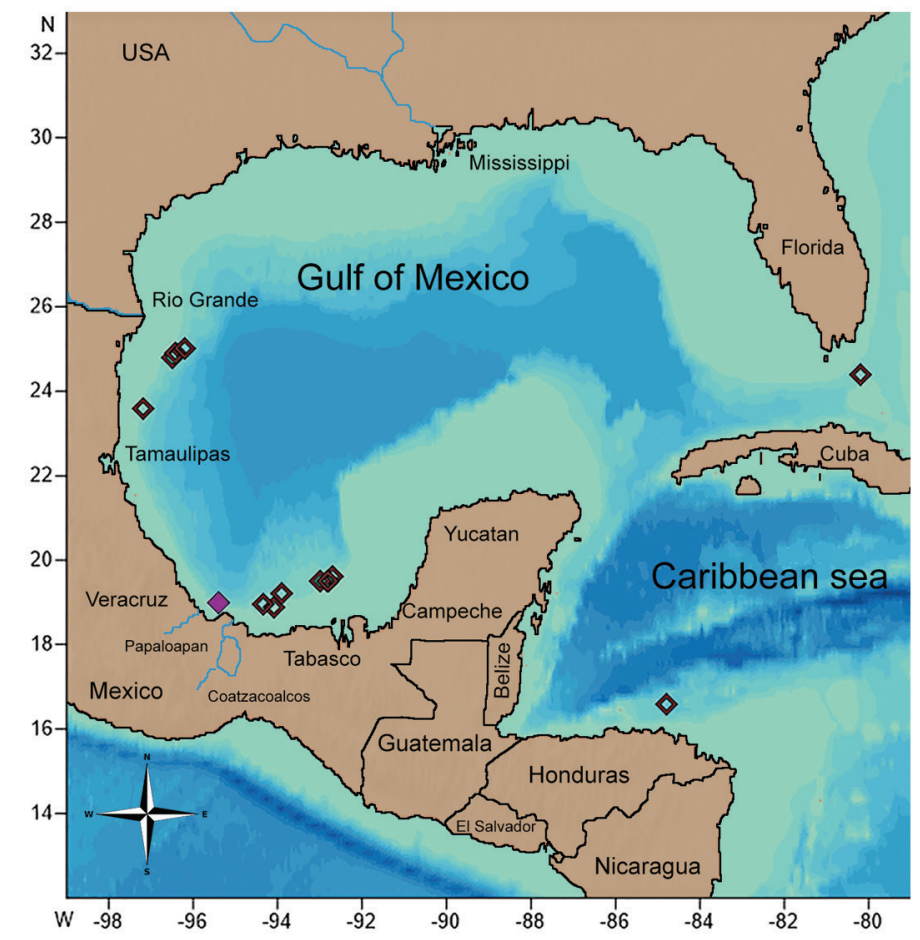

Fig. 6. Geographic distribution of M. xandaros. In purple: type locality (Veracruz, Mexico). 
\& 92०49'18.48" W; $567 \mathrm{~m} ; \mathrm{N}=2$ ). ICMLUNAM 12679 (Laguna Mecoacan, Tabasco, Mexico; 19³2’31.56” N \& 931'29.82” W; 714 $\mathrm{m} ; \mathrm{N}=3$ arm fragments). ICML-UNAM 12704 (Frontera, Tabasco, Mexico; 1940'7.32" N \& 92 $466^{\prime} 14.76 " \mathrm{~W} ; 812 \mathrm{~m} ; \mathrm{N}=11$ arm fragments). USNM E 11420 (Veracruz, Mexico;19²’35.442” N \& 95²7’24.743” W; 475 m; N=1). USNM E 11421 (Veracruz, Mexico; 19²'35.442” N \& 95²7'24.743” W; 475 m; N=1). USNM E 20951 (North of Cay Sal Bank, Florida, United States; $24^{\circ} 28^{\prime} 0.12^{\prime \prime} \mathrm{N}$ \& 80¹6'0.12" W; 802-805 m; N=1). USNM E 20984 (Explorer Bank, Honduras; 1640'12" $\mathrm{N} \& 82^{\circ} 49^{\prime} 47.9$ " $\mathrm{W} ; 366 \mathrm{~m}$; $\mathrm{N}=1$ ). USNM E 34898 (South to Phleger Basin, Texas, Unit-

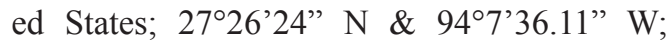
$1280 \mathrm{~m} ; \mathrm{N}=1$ ).

\section{DISCUSSION}

Midgardia xandaros is considered the starfish with the longest arms, being described from a specimen with $\mathrm{R}=680 \mathrm{~mm}$ by Downey (1972). Since its designation as a new species, only Downey (1973), Downey (1986) and Clark and Downey (1992) added notes on its taxonomy and phylogenetic position within Brisingida from three specimens (USNM E11420, holotype; USNM E11421, paratype; USNM E20984, Honduras). These descriptions were mainly based on external taxonomic characters such as the shape of madreporite, arms, abactinal, marginal, terminal, oral, ambulacral and adambulacral plates and their respective spines. However, detailed descriptions or illustrations about ossicle arrangement, spine and pedicellariae disposition, and their structures were not provided.

After the examination and dissection of its skeleton, we found that the papilliform appearance of abactinal plates of the disk described by Downey (1986) and Clark and Downey (1992) is due to the presence of a high boss and acute abactinal spinelet. In addition, the costae plates previously described as "bar-shaped" are actually irregularly cruciform because of their slightly distal and proximal costae articulations. The numerous, irregularly round, flattened, fenestrated, thin plates dispersed between costae rows, as described by Downey (1972), Downey (1973), Downey (1986) and Clark and Downey (1992), are referred to here as intercostal plates; their weak stereom make them fragile and irregularly shaped.

Downey (1972), Downey (1973), Downey (1986) mentioned that terminal plates are wider than long, curved downwards and have cat's claw-like spinelets at their top. In this study, we did not include comments related to the terminal plates because the only specimens that present these plates are the ones reviewed by Downey. She also stated that marginal plates are triangular-shaped at the proximal part of the arms, and distally they are reduced to tubercles; however, the proximal ones are rectangular with short articulating areas and a robust, downwards-pointing boss. Regarding the presence of inferomarginal spines, we also note their absence at the basal region of the arms, but along and beyond it, there is not a defined pattern of attachment. They may be present in two or three consecutive inferomarginal plates and absent in the following one or two plates or have an alternate presence.

Both Downey (1972), Downey (1973), Downey (1986) and Clark and Downey (1992) described the adambulacral plates as vertebralike. This appearance might be due to their robustness, length, height and short adradial extensions. Moreover, they considered the ambulacral plates as T-shaped, with a narrow waist and short, thick apex. This apex is actually the base, and even though their wings seem to be large, SEM photos reveal their poor development, being so short; the true apex is high, round and the base is quite angular due to their attachment with inferomarginal plates.

While dissociating an oral frame fragment, we recognized two prominent, longer than wide oral plates, narrower first ambulacral plates, and a longer than wide odontophore. Downey (1972) stated that the "calcareous ring" is composed of the massive, tumid, fused first ambulacrals and the oral plates, that are smaller than the first adambulacral plates; in 
fact, the first ambulacrals are not fused, and the oral plates are bigger than first ambulacrals and adambulacrals. Their apparent "fusion" might be due to the presence of thick, hard attachment muscles both between first ambulacral and oral plates and within them.

We also remark that the outer wall of the disk is not made up of the second ambulacral and second adambulacral plates together with the first marginal plates, as Downey (1972), Downey (1973), Downey (1986) mentioned; instead, it is composed of the first adambulacral plates. However, we do confirm that the second ambulacral plates are highly compressed, as Downey (1972) noted, having almost unnoticeable wings. With respect to the first marginal plates, in this study we noticed that they are joined to the odontophore, and they do not completely separate the first adambulacral plates as Downey described.

Concerning pedicellariae distribution, Downey (1972), Downey (1973), Downey (1986) and Clark and Downey (1992) affirmed that there are no pedicellariae on the abactinal surface of the disk. However, we found large crossed pedicellariae with $\mathrm{C}$-shaped valves scattered on the abactinal membrane of the disk, which were previously only noticed in the ambulacral furrow. Clark and Downey (1992) provided illustrations of complete large and tiny pedicellariae, and even though the basal plate was not presented, the general morphology of both pedicellariae was shown. They illustrated C-shaped valves pedicellariae with 17 teeth on the medial projection and an angular base; however, SEM photos showed that the number and development of these teeth might be variable, having up to 25 teeth and some marked spaces between them, and the base is slightly rounded. Likewise, Clark and Downey (1992) described tiny pedicellariae with a robust appearance, and valves with an extensive medial projection and canine area. On the contrary, our SEM images of these pedicellariae revealed valves of a slender shape and shorter denticulation areas.

\section{Observations on brisingids morphol-} ogy: Comprehensive descriptions about brisingids ossicle, spination and pedicellariae have been given for only a few species: Brisinga costata Verrill, 1884; Freyella elegans (Verrill, 1884); Brisingaster robillardi de Loriol, 1883; Novidinia helenae Rowe, 1989; Novodinia antillensis (A. H. Clark, 1934) and Odinella nutrix Fisher, 1940 (Ludwig, 1897; Emson \& Young, 1994; Mah, 1999; Gale, 2011; Fau \& Villier, 2018; Fau \& Villier, 2019), with only $B$. coronata being fully described by Sars (1875). Due to the low availability of specimens of $M$. xandaros and descriptions of full skeletons of brisingids, a morphological comparison within Brisingida was not carried out. Therefore, the following comments are restricted to the general morphology of a brisingid, adding new observations which will be useful for future comparative studies.

The oral frame had been considered as an internal, immobile ring whose ossicles are a partially or completely fused ring (Spencer \& Wright, 1966; Blake, 1987; Gale, 1987; Mah, 1999; Gale, 2011). In addition to this, Fau and Villier (2019) stated that oral, first ambulacral plates and odontophore are partially fused, remarking that the odontophore is not fused with the other two plates, and explaining that the understanding of a fused oral frame might be due to the difficulty of dissociating their plates. However, later in their discussion they mentioned that these ossicles are imbricated rather than fused. We also observed an odontophore separated from the first ambulacral and oral plates, being the first ossicle to be isolated, but also well-defined, separated first ambulacrals from the oral plates for $M$. xandaros. Therefore, we agree with them that the oral frame ossicles are not fused.

According to Fau and Villier $(2018,2019)$, the iioa articulation reinforces the rigidity of the oral frame due to its rugose surface which is above to aciim on the orals. The oral plate of $M$. xandaros in interradial view also shows both iioa and abiim with extensive surface, and an actinal, narrow aciim. Likewise, the odontophore has the general brisingid shape "longer 
than wide", being attached to oral plates by only poda mentioned by them.

Sars (1875) illustrated a fragment of the oral frame of $B$. coronata, showing an attachment between the "dorsal marginal plates" and the "wedge plate" which represents the odontophore. This attachment was also observed in the oral frame of $M$. xandaros; therefore, we consider odomim as the articulation joining the odontophore with the first inferomarginal plates. Gale (2011) stated that the axillary ossicle is homologous to the odontophore, which articulates with both oral and marginal ossicles through ima (inferomarginal articulation on axillary/odontophore) in the extinct Calliasterella mira (Trautschold, 1879) but absent in neoasteroid odontophores. We suggest further study on the articulation between odontophores and inferomarginal plates to evaluate their correspondence with ima.

Fau and Villier (2019) mentioned that Brisingida does not have an adoral carina even the first adambulacral plates may be abutted, here we also noticed that the first and second adambulacral plates are abutted interradially through the inferomarginal plates. In addition to this, they also noted that superambulacral and actinal plates are absent, and the crest on the adambulacral plates separates the almost equal expanded padam and dadam as we observed in M. xandaros.

Articulations between abactinal plates on the arm of asteriids and zoroasterids have been recognized. Blake (1987) stated that one or more articular flanges are present both in irregular or cruciform ossicles of asteriids. Likewise, node and connecting ossicles were defined for the abactinal mesh of Asterias rubens Linnaeus, 1758 which are joined through processes (Schwertmann et al., 2019). Fau and Villier (2019) considered these two types of ossicles as primary and secondary plates, respectively, remarking that primary plates hold spines and overlap other abactinal plates through four or more articular facets, also called lobes, in Forcipulatacea Blake, 1987. For example, the abactinal plates of the arms of Zoroaster fulgens Thomson, 1873 have two lateral articulation facets which overlap to carinal and marginal plates (Fau and Villier, 2018). Following this assumption, they named primary abactinals to the plates of the costae rows in brisingids. Since brisingids do not have carinal series (Fau and Villier, 2019), here the primary abactinals are called costae plates to remark their correspondence in costae rows. Therefore, each costae plate has two lateral costcost articulations which allow the connection with the adjacent costae plate, forming the transverse costae rows.

Regarding the robustness of adambulacral, ambulacral and inferomarginal plates, it was observed that the second ambulacral plate is the most compressed one, and the first ambulacral plates are the highest, most angular. Beyond the gonadal region, the ambulacral plates have more conspicuous wings and shaft, but their apex is less developed; meanwhile, the adambulacral plates are longer than wide, quite narrow transversally with an inconspicuous crest, and inferomarginal plates are almost tubercles. Spencer and Wright (1966), Gale (1987), Blake (1987) and Fau and Villier (2019) mentioned that brisingids have a weak skeleton, such as in the abactinal plates of the disk, and that the furrow of ambulacral plates is irregular. Particularly, M. xandaros ossicles tend to decrease in size and height, shortening or elongating in shape in the case of adambulacral plates, further from the base of the arm; additionally, the distal ambulacral plates have an almost inconspicuous furrow.

As Downey (1972), Downey (1986), Clark and Downey (1992) and Fau and Villier (2019) remarked, there is only one row of marginal plates called inferomarginals; this study follows the same name for brisingids marginal plates. Likewise, Fau and Villier (2019) mentioned that these plates do not overlap with each other, which might be due to separate or incomplete costae rows; nevertheless, both proximal and gonadal inferomarginal plates of $M$. xandaros abut by imim articulation and lied on ambulacral plates through amim. This means that inferomarginals are not necessarily joined to each costae plate because of the 
presence of other small inferomarginal plates. Distal to the gonadal region, the inferomarginal plates alternate with ambulacral plates.

Lastly, straight pedicellariae were not observed, only recognizing two types of crossed pedicellariae: large, C-shaped, and tiny, spatulate-shaped. Apart from the lack of straight pedicellariae, the presence of a medial projection with teeth and less than three rows of distal teeth has been noted as unique characters of brisingids (Gale, 1987; Fau \& Villier, 2019).

It has been demonstrated that ophiuroids ossicle morphology provides useful taxonomic information from order to specific level (Martynov, 2010; Pineda-Enríquez, BribiescaContreras, Solís-Marín, Laguarda-Figueras, \& O'Hara, 2017; O'Hara, Stöhr, Hugall, Thuy, \& Martynov, 2018). In the class Asteroidea, Villier, Blake, Jagt and Kutscher (2004) remarked on the taxonomic importance of ossicle morphology; however, most of the studies about asteroids ossicles have provided insights at an order level, and in the particular case of brisingids, there is still a significant gap in information about their skeleton and spination.

Fau and Villier (2019) stressed that more studies on oral frame structure are needed, but we also recommend undertaking comparative descriptions focused on marginal, adambulacral and ambulacral plates, since the position of articulation and muscles such as dada, dadam and padam, and crest, sturdiness and sharpness of these plates seems to be variable along the arm. As the costae rows are absent in Freyellidae, we suggest carrying out a complete description of a species of this family in order to get a holistic understanding of the arm of Brisingida.

In addition to the description of these ossicles, presented for the first time is the morphology of abactinal, first adambulacral, first and subsequent inferomarginal, and the distal arm plates, as well as abactinal spines and $\mathrm{C}$-shaped crossed pedicellariae for a brisingid species. Therefore, the present study expands on the morphological description of M. xandaros and contributes to the knowledge of brisingids morphology, providing the most extensive morphological description for a brisingid species using SEM to date which gives insights for future taxonomic studies of this order.

Ethical statement: authors declare that they all agree with this publication and made significant contributions; that there is no conflict of interest of any kind; and that we followed all pertinent ethical and legal procedures and requirements. All financial sources are fully and clearly stated in the acknowledgements section. A signed document has been filed in the journal archives.

\section{ACKNOWLEDGMENTS}

We would like to thank to Ma. Esther Diupotex Chong and Alicia Durán González for their technical support at the CNE, ICML, UNAM. To Ma. Berenit Mendoza Garfias (IB, UNAM) and Laura E. Gómez Lizárraga (ICML, UNAM) for the SEM photographs, to Gloria I. Rosales-Contreras for her help to take some additional photos. To Susana Guzmán Gómez (IB, UNAM) for her technical support with the multifocal photography. Magdalena De los Palos-Peña would like to thank to CONACYT for the scholarship (number 929010) and to Dave Pawson, William Moser and the Invertebrate Zoology's, Smithsonian staff for their support. Finally, the authors would like to thank Matthew G. Lovegrove, Andrea A. Caballero-Ochoa and Duncan A. Purdie for their valuable comments on the manuscript's English.

\section{RESUMEN}

Morfología del endoesqueleto y ornamentación
de la estrella de mar Midgardia xandaros
(Brisingida: Brisingidae) en el Golfo de México

Introducción: Las estrellas de mar de profundidad del orden Brisingida tienen una distribución casi global, sin embargo, han sido poco estudiadas debido a su profunda distribución batimétrica y esqueleto frágil. Objetivo: Describir la morfología externa e interna de Midgardia xandaros incluyendo el arreglo de las placas del esqueleto mediante técnicas de microscopía multifocal y electrónica 
de barrido (MEB). Métodos: Se examinó un total de 21 ejemplares, incluyendo 27 fragmentos de brazos, provenientes del Golfo de México y Honduras. Dos de estos ejemplares fueron disectados. Resultados: Se presenta la descripción de pedicelarios; placas abactinales, intercostales, inferomarginales, adambulacrales, ambulacrales, orales y odontóforo, y sus espinas, enfatizando los sitios de articulaciones e inserción de músculos. Se reconocieron pedicelarios con valvas con forma de $\mathrm{C}$, y pequeños pedicelarios cuyas valvas poseen áreas de denticulación cortas. Conclusiones: La descripción morfológica de M. xandaros es ampliada, presentado por primera vez la morfología de las placas abactinales, primera adambulacrales, primera y subsecuentes inferomarginales, espinas abactinales y pedicelarios con valvas con forma de "C", así como las placas distales de los brazos para una especie del orden Brisingida.

Palabras clave: osículos; morfología interna; pedicelarios; espinas; mar profundo.

\section{REFERENCES}

Agassiz, A. (1877). North American starfishes. Memoirs of the Museum of Comparative Zoology at Harvard, 5(1), 1-196.

Armstrong-Altrin, J.S., Machain-Castillo, M.L., RosalesHoz, L., Carranza-Edwards, A., Sánchez-Cabeza, J.A. \& Ruíz-Fernández, A.C. (2015). Provenance and depositional history of continental slope sediments in the Southwestern Gulf of Mexico unraveled by geochemical analysis. Continental Shelf Research, 95, 15-26.

Baranova, Z.I. (1957). Echinoderms of the Bering Sea. Investigations of Far-East Seas, 4, 149-266.

Benavides-Serrato, M., Borrero-Pérez, G.H. \& DíazSánchez, C.M. (2011). Equinodermos del Caribe Colombiano II: Echinoidea y Holothuroidea. Serie de Publicaciones Especiales del Invemar, 22, 384.

Blake, D.B. (1987). A classification and phylogeny of postPalaeozoic sea stars (Asteroidea: Echinodermata). Journal of Natural History, 21, 481-528.

Clark, A. H. (1934). A new starfish from Puerto Rico. Smithsonian Miscellaneous Collections, 91(14), 1-13.

Clark, A.M. \& Mah, C. (2001). An index of names of recent Asteroidea-Part 4: Forcipulatida and Brisingida. In J.M. Lawrence \& M. Jangoux (Eds.), Echinoderm studies 6 (pp. 229-347). Netherlands: A.A. Balkema.

Clark, A.M. \& Downey, M.E. (1992). Starfishes of the Atlantic (pp. 794). London, UK: Chapman \& Hall.
Chia, F.S. \& Amerongen, E. (1975). On the prey-catching pedicellariae of a starfish, Stylasterias forreri (de Loriol). Canadian Journal of Zoology, 53, 748-755.

de Loriol, P. (1883). Catalogue raisonne des échinodermes recueillis par M. V. de Robillard à l'Ille Maurice. Mémoires de la Société de physique et d'histoire naturelle de Genève, 28(8), 1-64.

de Loriol, P. (1887). Notes pour servir à l'étude des Echinodermes, no. 2. Recueil Zoologique Suisse, 4(3), 365-407.

Downey, M.E. (1972). Midgardia xandaros new genus, new species, a large brisingid starfish from the Gulf of Mexico. Proceedings of the Biological Society of Washington, 84, 421-426.

Downey, M.E. (1973). Starfishes from the Caribbean and the Gulf of Mexico. Smithsonian Contributions to Zoology, 126, 1-158.

Downey, M.E. (1986). Revision of the atlantic Brisingida (Echinodermata: Asteroidea), with description of a new genus and family. Smithsonian Contributions to Zoology, 435, 1-57.

Durán-González, A., Laguarda-Figueras, A., Solís-Marín, F.A., Buitrón-Sánchez, B.E., \& Torres-Vega, J. (2005). Equinodermos (Echinodermata) de las aguas mexicanas del Golfo de México. Revista de Biología Tropical, 53(3), 53-68.

Emson, R.H. \& Young, C.M. (1994). Feeding mechanism of the brisingid starfish Novodinia antillensis. Marine Biology, 118, 433-442.

Fau, M. \& Villier, L. (2018). Post-metamorphic ontogeny of Zoroaster fulgens Thompson, 1873 (Asteroidea, Forcipulatacea). Journal of Anatomy, 233, 644-665.

Fau, M. \& Villier, L. (2019). Comparative anatomy and phylogeny of the Forcipulatacea (Echinodermata: Asteroidea): insights from ossicle morphology. Zoological Journal of the Linnean Society, 20, 1-32.

Fautin, D., Dalton, P., Incze, L.S., Leong, J.C., Rosenberg, A., Sandifer, P., . . . Wolff, N. (2010). An overview of marine biodiversity in United States waters. PLoS One, 5(8), e11914.

Fisher, W.K. (1917). New genera and species of Brisingidae. Annals and Magazine of Natural History, 20(8), 418-431.

Fisher, W.K. (1918). Notes on Asteroidea II. Annals and Magazine of Natural History, 9(2), 103-111.

Fisher, W.K. (1928). Sea stars from the Arcturus Oceanographic Expedition. Zoologica, 8, 487-493.

Fisher, W. K. (1940). Asteroidea. Discovery Reports, 20, 69-306. 
Gale, A.S. (1987). Phylogeny and classification of the Asteroidea (Echinodermata). Zoological Society of the Linnean Society, 89, 107-132.

Gale, A. (2011). The phylogeny of post-Palaeozoic asteroidea (Neoasteroidea, Echinodermata). Special Papers in Palaeontology, 85, 5-112.

Gale, K., Mah, C., Hamel, J.F. \& Mercier, A. (2014). New records of brisingidan asteroids (Asteroidea: Brisingida) in eastern Canada. Marine Biodiversity Records, 7(e125), 1-5.

Linnaeus, C. (1758). Systema naturae per regna tria naturae, secundum classes, ordines, genera, species, cum characteribus, differentiis, synonymis, locis $(824$ pp.). Stockholm, Sweden: Laurentius Salvius.

Ludwig, H. (1897). Die seesterne des Mittelmeeres. Fauna und flora des Golfes von Neapel, 24, 1-491.

Mah, C.L. (1999). Taxonomy of the south Pacific brisingidan Brisingaster robillardi (Asteroidea) with new ontogenetic and phylogenetic information. Zoosyste$m a, 21(3), 535-546$.

Mah, C.L. (2016). A new species of Brisingines from the Hawaii Undersea Military Munitions Assessment Area with an overview of Hawaiian brisingid in situ video observations and functional morphology of subambulacral spines (Forcipulatacea; Asteroidea). Deep-Sea Research II, 128, 43-52.

Mah, C.L. \& Blake, D.B. (2012). Global Diversity and phylogeny of the Asteroidea (Echinodermata). PloS ONE, 7(4), e35644.

Martynov, A. (2010). Reassessment of the classification of the Ophiuroidea (Echinodermata), based on morphological characters. I. General character evaluation and delineation of the families Ophiomyxidae and Ophiacanthidae. Zootaxa, 2697, 1-154.

McKnight, D.G. (2006). Echinodermata: Asteroidea (Seastars). 3. Orders Velatida, Spinulosida, Forcipulatida, Brisingida with adenda to Paxillosida, Valvatida. Auckland, New Zealand: National Institute of Water and Atmospheric Research.

Miloslavich, P., Díaz, J.M., Klein, E., Alvarado, J.J., Díaz, C., Gobin, J., . . . Ortiz, M. (2010). Marine biodiversity in the Caribbean: regional estimates and distribution patterns. PLOS ONE, 5(8), e11916.

O’Hara, T.D., Stöhr, S., Hugall, A.F., Thuy, B. \& Martynov, A. (2018). Morphological diagnoses of higher taxa in Ophiuroidea (Echinodermata) in support of a new classification. European Journal of Taxonomy, $416,1-35$.

Palanisamy, H., Becker, M., Meyssignac, B., Henry, O. \& Cazenave, A. (2012). Regional sea level change and variability in the Caribbean Sea since 1950. Journal of Geodetic Science, 2(2), 125-133.
Pequegnat, W.E., Gallaway, B.J. \& Pequegnat, L.H. (1990). Aspects of the ecology of the deep-water fauna of the Gulf of Mexico. American Zoologist, 30, 45-64.

Pineda-Enríquez, T., Bribiesca-Contreras, G., Solís-Marín, F.A., Laguarda-Figueras, A. \& O’Hara, T. (2017). New species of the genus Ophiolepis Müller \& Troschel, 1840 (Echinodermata: Ophiuroidea: Ophiolepididae). Journal of the Marine Biological Association of the United Kingdom, 98(8), 2049-2065.

Ramos-Vázquez, M.A., Armstrong-Altrin, J.S., Rosales-Hoz, L., Machain-Castillo, M.L. \& CarranzaEdwards, A. (2017). Geochemistry of deep-sea sediments in two cores retrieved at the mouth of the Coatzacoalcos River delta, western Gulf of Mexico, Mexico. Arabian Journal of Geosciences, 10, 148.

Rowe, F.W.E. (1989). Nine new deep-water species of Echinodermata from Norfolk Island and Wanganella Bank, northeastern Tasman Sea, with a checklist of the echinoderm fauna. Proceedings of the Linnean Society of New South Wales, 111(1-4), 257-292.

Sars, G.O. (1875). On some remarkable forms of animal life from the great deeps off the Norwegian coast. II. Researches on the structure and affinity of the genus Brisinga based on the study of a new species, Brisinga coronata. Oslo, Norway: Christiana University.

Schwertmann, L., Focke, O. \& Dirks, J-H. (2019). Morphology, shape variation and movement of skeletal elements in starfish (Asterias rubens). Journal of Anatomy, 234, 656-667.

Sladen, W. P. (1889). The Asteroidea. Report on the scientific results of voyage of H. M. S. "Challenger". Zoology, 30, 1-935.

Solís-Marín, F.A., Alvarado, J.J., Abreu-Pérez, M., Aguilera, O., Alió, J., Bacallado-Aránega, J.J., . . . Williams, S.M. (2013). Appendix. In J.J. Alvarado \& F.A. SolísMarín (Eds.), Echinoderm Research and Diversity in Latin America (pp. 543-654). Berlin: Springer Berlin Heidelberg.

Spencer, W.K. \& Wright, C.W. (1966). Asterozoans. In R.C. Moore (Ed.), Treatise on invertebrate paleontology (pp. U7-107). Kansas, United States: University of Kansas Press.

Thomson, C.W. (1873). The depths of the sea (527 pp). London, UK: MacMillan and Co.

Trautschold, H. (1879). Die Kalkbruche von Mjatschkowa, part 3. Nouveaux Mémoires de la Société Impériale des Naturalistes de Moscou, 14, 101-180.

Tortonese, E. (1958). Euclasteroidea: nuovo ordine di asteroidi (Echinodermi). Doriana, 2(88), 1-3.

Turner, R.E. \& Rabalais, N.N. (2019). The Gulf of Mexico. In C. Sheppard (Ed.), World Seas: an environmental 
evaluation: Volume I: Europe, the Americas and West Africa (pp. 445-464). London, United Kingdom: Elsevier.

Ward, C.H. \& Tunnell Jr, J.W. (2017). Habitats and biota of the Gulf of Mexico: an overview. In C.H. Ward (Ed.), Habitats and biota of the Gulf of Mexico: before the Deep-water horizon oil spill (pp. 1-54). New York, United States: Springer Nature.

Verrill, A.E. (1884). Notice on the remarkable marine fauna occupying the outer banks off the southern coast of New England, no. 10. American Journal of Science, 3, 28 (127), 378-384.

Vickery, M.S. \& McClintock, J.B. (2000). Comparative morphology of tube feet among the Asteroidea: phylogenetic implications. American Zoologist, 40, 355-364.
Viguier, C. (1879). Anatomie comparée du squelette des Stellérides. Archives de Zoologie Expérimentale et Générale, 7, 1-183.

Villier, L., Blake, D., Jagt, J. \& Kutscher, M. (2004). A preliminary phylogeny of the Pterasteridae (Echinodermata, Asteroidea) and the first fossil record: Late Cretaceous of Germany and Belgium. Paläontologische Zeitschrift, 78(2), 281-299.

Zhang, R., Wang. C., Zhou, Y. \& Zhang. H. (2019). Morphology and molecular phylogeny of two new species in the genus Freyastera (Asteroidea: Brisingida: Freyellidae), with a revised key to close species and ecological remarks. Deep-Sea Research Part I: Oceanographic Research Papers, 154(103163), 1-11.

Zhang, R., Zhou, Y., Xiao, N., \& Wang, C. (2020). A new sponge-associated starfish, Astrolirus patricki sp. nov. (Asteroidea: Brisingida: Brisingidae), from the northwestern Pacific seamounts. PeerJ, 8, e9071. 
APPENDIX 1

Terminology and abbreviations used in this study. *Definitions modified.

\begin{tabular}{|c|c|c|}
\hline Term & Definition & Author/Present study \\
\hline Abactinal view & $\begin{array}{l}\text { View of the upper surface opposite to mouth (above marginals) } \\
\text { of the ossicle }\end{array}$ & Clark and Downey (1992) \\
\hline abd & Abductor muscle on crossed forcipulate pedicellariae & Emson and Young (1994) \\
\hline abiim & Interoral abactinal muscle & Fau and Villier (2019) \\
\hline abtam & Transverse abactinal interambulacral muscle & Fau and Villier (2019) \\
\hline aciim & Interoral actinal muscle & Fau and Villier (2019) \\
\hline actam & Transverse actinal interambulacral muscle & Fau and Villier (2019) \\
\hline Actinal view & $\begin{array}{l}\text { View of the lower surface opposite to anus (below marginals) } \\
\text { of the ossicle }\end{array}$ & Clark and Downey (1992) \\
\hline add & Adductor muscle on crossed forcipulate pedicellariae & Emson and Young (1994) \\
\hline Adradial extension & Adambulacral carinae on the plate margin & Fau and Villier (2018) \\
\hline amim & Ambulacral-inferomarginal articulation & Present study \\
\hline Articular ridge & $\begin{array}{l}\text { Projection of the basal plate where crossed forcipulate pedicellariae } \\
\text { valves rest }\end{array}$ & Emson and Young (1994) \\
\hline Basal plate & $\begin{array}{l}\text { Ossicle joining two valves and attaching abductor and adductor } \\
\text { muscles located in the basal part of the crossed forcipulate } \\
\text { pedicellariae }\end{array}$ & Emson and Young (1994) \\
\hline $\begin{array}{l}\text { Base (of the spines/ } \\
\text { spinelets) }\end{array}$ & $\begin{array}{l}\text { Coarse, proximal end of the spine that articulates to the boss } \\
\text { of the ossicle }\end{array}$ & Present study \\
\hline $\begin{array}{l}\text { Base (of the } \\
\text { ambulacrals) }\end{array}$ & $\begin{array}{l}\text { Inferior part that articulates with two adjacent adambulacral ossicles } \\
\text { through a transverse articular ridge on its actinal surface and proximal } \\
\text { and distal wing-like processes on which proximal (padam) and distal } \\
\text { (dadam) adambulacral-ambulacral muscles insert }\end{array}$ & $\begin{array}{l}\text { Gale (2011); Fau and Villier } \\
\text { (2019) }\end{array}$ \\
\hline Body & $\begin{array}{l}\text { Actinal part of the ossicle bearing the spines, the odom and aciim } \\
\text { muscles on the interradial side, and the iioa articulation }\end{array}$ & Fau and Villier (2019) \\
\hline Boss & A mound-like projection for spine attachment. & Turner and Dearborn (1972) \\
\hline Spine pit & $\begin{array}{l}\text { A central depression in some bosses. A notch completely or partially } \\
\text { surrounded by an articulation area in a boss. }\end{array}$ & $\begin{array}{l}\text { Turner and Dearborn (1972). } \\
\text { Fau and Villier (2019) (as a } \\
\text { pustule). }\end{array}$ \\
\hline Canine & $\begin{array}{l}\text { Canine-like tooth on upper part of crossed forcipulate } \\
\text { pedicellariae valves }\end{array}$ & Chia \& Amerongen (1975) \\
\hline costcost & Costae-costae ossicle articulation & Present study \\
\hline Crest & $\begin{array}{l}\text { Ridge separating the muscle insertions, padam and dadam on the } \\
\text { adambulacrals (brisingids and zoroasterids). Ridge or elevation }\end{array}$ & *Fau and Villier (2019) \\
\hline dada & $\begin{array}{l}\text { Ambulacral/adambulacral articulation (distal on the ambulacral, } \\
\text { proximal on the adambulacrals) }\end{array}$ & Fau and Villier (2019) \\
\hline dadam & Distal ambulacral/adambulacral muscle, on the ambulacrals & Fau and Villier (2019) \\
\hline Diastema & $\begin{array}{l}\text { Gap between the distal teeth and median teeth on crossed forcipulate } \\
\text { pedicellariae valves }\end{array}$ & Fau and Villier (2019) \\
\hline Distal & Direction toward the tip of the arm & Fau and Villier (2018) \\
\hline dicoa & $\begin{array}{l}\text { Trace on the oral plates of the articulation between the oral and the } \\
\text { first ambulacral ossicle }\end{array}$ & Fau and Villier (2019) \\
\hline dicoam & Oral/first ambulacral distal muscle insertion, on the oral & Fau and Villier (2019) \\
\hline doda & Distal oral/odontophore articulation & Fau and Villier (2019) \\
\hline Furrow & $\begin{array}{l}\text { Furrow on the distal process of the first ambulacrals and on the shaft } \\
\text { of ambulacrals }\end{array}$ & Fau and Villier (2019) \\
\hline $\begin{array}{l}\text { Head (of the } \\
\text { ambulacrals) }\end{array}$ & $\begin{array}{l}\text { Superior part that articulates with the corresponding ambulacral plate } \\
\text { of the opposing column across the mid-radial line by means of an } \\
\text { interdigitating dentition }\end{array}$ & Gale (2011) \\
\hline
\end{tabular}




\begin{tabular}{|c|c|c|}
\hline Term & Definition & Author/Present study \\
\hline iioa & Interoral articulation & Fau and Villier (2019) \\
\hline imabt & Inferomarginal-abactinal articulation & *Fau and Villier (2018) \\
\hline imim & Inferomarginal-inferomarginal articulation & Present study \\
\hline interadam & Interadambulacral muscle & Fau and Villier (2019) \\
\hline Interradial view & $\begin{array}{l}\text { View of the surface of the ossicle that faces away from the radial } \\
\text { plane (with respect to the midradial line along the arms) }\end{array}$ & *Fau and Villier (2018) \\
\hline lia & Longitudinal interambulacral articulation & Fau and Villier (2019) \\
\hline$\underline{\lim }$ & Longitudinal interambulacral muscle & Fau and Villier (2019) \\
\hline Medial projection & Mid process with teeth on crossed forcipulate pedicellariae valves & Chia \& Amerongen (1975) \\
\hline Median teeth & $\begin{array}{l}\text { Transversal tooth on upper part of crossed forcipulate pedicellariae } \\
\text { valves }\end{array}$ & Chia \& Amerongen (1975) \\
\hline odom & Odontophore-oral muscle & Fau and Villier (2019) \\
\hline odomim & Odontophore-inferomarginal articulation & Present study \\
\hline pada & $\begin{array}{l}\text { Ambulacral-adambulacral articulation, (proximal on the ambulacral, } \\
\text { distal on the adambulacral) }\end{array}$ & Fau and Villier (2019) \\
\hline padam & Proximal ambulacral-adambulacral muscle, on the ambulacral & Fau and Villier (2019) \\
\hline Plateau & $\begin{array}{l}\text { Flat area at the end of the abactinal ramus edge of the oral ossicle, } \\
\text { generally distinct from the latter by a change of slope, bearing the } \\
\text { doda articulation on the interradial side, and the complex dicoa/ } \\
\text { dicoam on the radial side }\end{array}$ & Fau and Villier (2019) \\
\hline poda & Proximal odontophore-oral articulation & Fau and Villier (2019) \\
\hline procoa & Proximal oral-first ambulacral articulation, on the orals & Fau and Villier (2019) \\
\hline procoam & Proximal oral-first ambulacral muscle on the oral & Fau and Villier (2019) \\
\hline Proximal & Direction toward the center of the disk & Fau and Villier (2018) \\
\hline $\mathrm{R}$ & Radio mayor (del centro del disco a la punta del brazo) & Clark and Downey (1992) \\
\hline r & Radio menor (del centro del disco a un borde interradial) & Clark and Downey (1992) \\
\hline Radial view & $\begin{array}{l}\text { View of the surface that faces towards the radial plane (with respect to } \\
\text { the midradial line along the arms) }\end{array}$ & $\mathrm{o}$ *Fau and Villier (2018) \\
\hline Ramus & $\begin{array}{l}\text { Abactinal extension of the oral ossicle, bearing the abiim muscle and } \\
\text { the poda articulation on the interradial side, and the complex procoa/ } \\
\text { procoam on the radial side of the ossicle }\end{array}$ & Fau and Villier (2019) \\
\hline riom & Interoral muscle & Fau and Villier (2019) \\
\hline rng & Passageway of the nervous oral ring & Fau and Villier (2019) \\
\hline rvg & $\begin{array}{l}\text { Groove along the oral ossicles in which lies the ring canal of the } \\
\text { ambulacral system }\end{array}$ & Fau and Villier (2019) \\
\hline $\begin{array}{l}\text { Shaft (of the } \\
\text { ambulacrals) }\end{array}$ & Middle part of the ambulacrals & $\begin{array}{l}\text { Gale (2011); Fau and Villier } \\
(2019) \text {. }\end{array}$ \\
\hline Shaft (of the spines) & Long section of the spines & Gale (2011) \\
\hline Teeth (of the ossicles) & $\begin{array}{l}\text { Imbricating teeth and socket structures, on the ambulacral head. } \\
\text { Similar structure can appear on the interradial side of the orals and of } \\
\text { adambulacrals of the adoral carina. }\end{array}$ & Fau and Villier (2019) \\
\hline $\begin{array}{l}\text { Teeth (of the } \\
\text { pedicellariae) }\end{array}$ & Sharply pointed spines on the valves of a pedicellariae & Emson and Young (1994) \\
\hline Terminal peg & $\begin{array}{l}\text { Extension of the basal plate to interlock closely with the crossed } \\
\text { forcipulate pedicellariae valves }\end{array}$ & Emson and Young (1994) \\
\hline Trabeculae & Parallel columns along the spine/spinelet & Gale (2011) \\
\hline Wing & $\begin{array}{l}\text { Process at the base of ambulacrals on which proximal (padam) and } \\
\text { distal (dadam) muscles insert }\end{array}$ & $\begin{array}{l}\text { Gale (2011); Fau and Villier } \\
\text { (2019) }\end{array}$ \\
\hline
\end{tabular}

